\title{
Late Mesolithic burials at Casa Corona (Villena, Spain): direct radiocarbon and palaeodietary evidence of the last forager populations in Eastern Iberia
}

\author{
Javier Fernández-López de Pablo a,b,*,1, Domingo C. Salazar-García c,g,h,1, \\ María Eulàlia Subirà-Galdacano ${ }^{\mathrm{d}, \mathrm{e}}$, Consuelo Roca de Togores ${ }^{\mathrm{f}}$, Magdalena Gómez-Puche ${ }^{\mathrm{g}}$, \\ Mike P. Richards ${ }^{c, i}$, Marco A. Esquembre-Bebiá ${ }^{\mathrm{j}}$ \\ a Institut Català de Paleoecologia Humana i Evolució Social (IPHES), Escorxador s/n, 43003 Tarragona, Spain \\ ${ }^{\mathrm{b}}$ Área de Prehistoria, Universitat Rovira $i$ Virgili, Avinguda Catalunya 35, 43002 Tarragona, Spain \\ ${ }^{c}$ Department of Human Evolution, Max-Planck Institute for Evolutionary Anthropology, Deutscher Platz 6, D-04103 Leipzig, Germany \\ ${ }^{\mathrm{d}}$ Unitat d'Antropologia Biològica, Departament de Biologia Animal, de Biologia Vegetal i d'Ecologia, Edifici C. Universitat Autònoma de Barcelona, \\ 08193 Bellaterra (Cerdanyola del Vallès), Barcelona, Spain \\ e Minoa Arqueologia i Serveis SL, Camí antic de Sant Cugat 145, 08193 Bellaterra (Cerdanyola del Vallès), Barcelona, Spain \\ ${ }^{\mathrm{f}}$ Marq, Plaza del Doctor Gómez Ulla, 03013 Alicante, Spain \\ ${ }^{g}$ Dept. de Prehistoria y Arqueologia, Universidad de Valencia, Avgda. Blasco Ibáñez, 28, 46010 València, Spain \\ ${ }^{\mathrm{h}}$ Research Group on Plant Foods in Hominin Dietary Ecology, Max Planck Institute for Evolutionary Anthropology, Deutscher Platz 6, D-04103 Leipzig, Germany \\ i Department of Anthropology, University of British Columbia, 6303 NW Marine Drive, Vancouver, BC V6T 1Z1, Canada \\ ${ }^{\mathrm{j}}$ Arpa Patrimonio S.L., Avda. Rodalet 23A, 03690 San Vicente del Raspeig, Alicante, Spain
}

\section{A R T I C L E I N F O}

\section{Article history:}

Received 21 May 2012

Received in revised form

26 August 2012

Accepted 1 September 2012

\section{Keywords:}

Late Mesolithic

Radiocarbon

Carbon and nitrogen isotopes

Diet

Mesolithic-Neolithic transition

\begin{abstract}
A B S T R A C T
Current knowledge about the Mesolithic-Neolithic transition in the Central and Western Mediterranean European regions is deeply limited by the paucity of Late Mesolithic human osteological data and the presence of chronological gaps covering several centuries between the last foragers and the first archaeological evidence of farming peoples. In this work, we present new data to fill these gaps. We provide direct AMS radiocarbon dating and carbon $\left(\delta^{13} \mathrm{C}\right)$ and nitrogen $\left(\delta^{15} \mathrm{~N}\right)$ stable isotope analysis were carried out on bone collagen samples of two single burials from the recently discovered open-air Late Mesolithic site of Casa Corona (Villena, Spain). The results shed new light on the chronology and subsistence patterns of the last Mesolithic communities in the Central Mediterranean region of the Iberian Peninsula. Radiocarbon results date the human remains and funerary activity of the site to 6059-5849 cal BC, statistically different from other Late Mesolithic sites and the earliest Neolithic contexts, and bridging the 500 yrs chronological gap of the Mesolithic-Neolithic transition from the area. Isotopic evidence shows that diet was based on terrestrial resources despite the proximity to the site of lagoon and marine ecosystems. This and previous isotope studies from the region suggest a lower reliance upon marine resources than for Atlantic and Cantabrian sites, although intra-regional patterns of neighbouring Mesolithic populations exhibit both fully terrestrial diets and diets with significant amounts of aquatic resources in them. We hypothesize that in the Central Mediterranean region of Spain the Late Mesolithic dietary adaptations imposed structural limits on demographic growth of the last foragers and favoured rapid assimilation by the earliest Neolithic populations.
\end{abstract}

(c) 2012 Elsevier Ltd. All rights reserved.

\footnotetext{
* Corresponding author. Institut Català de Paleoecologia Humana i Evolució Social (IPHES), Escorxador s/n, 43003 Tarragona, Spain. Tel.: +34 977558703.

E-mail addresses: jfernandez@iphes.cat (J. Fernández-López de Pablo), domingo_ carlos@eva.mpg.de (D.C. Salazar-García), Eulalia.Subira@uab.cat (M.E. SubiràGaldacano), crocat@dip-alicante.es (C. Roca de Togores), mgomez.puc@gmail.com (M. Gómez-Puche), richards@eva.mpg.de (M.P. Richards), arpapatrimonio@tele fonica.net (M.A. Esquembre-Bebiá).

1 These authors equally contributed to this manuscript.
}

\section{Introduction}

The Mesolithic-Neolithic transition in Western Europe involved likely both spread of farming groups and technologies and cultural interaction with local forager communities (Ammermann and Cavalli-Sforza, 1984; Rowley-Conwy, 2011; Zilhão, 2003). One of the most frequently debated issues is the specific role of the last Mesolithic hunter-gatherers in this process, particularly the 
question when and why foraging subsistence systems disappeared after the appearance of the first Neolithic material culture and whether or not such a phenomenon implied a population replacement or adoption by indigenous Mesolithic peoples.

In the Mediterranean regions of Spain, France and Italy, the archaeological record displays two main limitations to answering these questions. First, there is a scarcity of directly dated human remains securely attributed to the Late Mesolithic period. In contrast to the Atlantic European regions, there are very few Late Mesolithic funerary contexts and human samples in the Central and Western Mediterranean, making it difficult to ascertain palaeodietary and palaeodemographic patterns that define the relationship between populations and resources in terms of carrying capacity. Secondly, the presence of chronological gaps of several centuries between the last Mesolithic and the first Neolithic archaeological contexts is documented in regional studies in the Valencian region (McClure et al., 2008), Southern France (Binder, 2000) and Italy (Biagi, 2003). In all these areas, lithic traditions based on Mesolithic trapezoid microliths (Castelnovian in Italy, Tardenoisian in Southern France and Cocina in Eastern Spain) predate the appearance of the first Neolithic Impressed and Cardial cultures (Guilaine and Manen, 2007).

In this context, radiocarbon and palaeodietary studies of Late Mesolithic human remains are important lines of evidence since they provide a starting point for tracking subsistence changes in populations directly involved in the Neolithisation process.

In this paper we present a study case of two Late Mesolithic burials from the recently discovered site of Casa Corona in the Central Mediterranean region of Spain (Fig. 1). Radiocarbon dates directly obtained from human samples are compared with the chronology of individual short-lived events from different Late Mesolithic and Early Neolithic contexts in this area. Then we discuss Iberian subsistence patterns during the Late Mesolithic in a broader Western Mediterranean context.

\section{The Late Mesolithic site of Casa Corona}

\subsection{Site description}

Casa Corona is an open-air site located in Villena (Alicante, Spain), in the upper course of the Vinalopó River, about $80 \mathrm{~km}$ from the coast. This area occupies a wide natural corridor with an average altitude of 500 m.a.s.l. dominated by endorheic lagoons and ponds. The site was settled on the northern margin of an endorheic basin.

Archaeological material from Late Mesolithic and Chalcolithic periods was excavated over three months in 2008 by Arpa Patrimonio S.L., in a rescue program resulting from the construction of a new high-speed rail network. The north sector of the site comprises the archaeological structures and layers dating to the Late Mesolithic phase (Fig. 2). Over $565 \mathrm{~m}^{2}$ were excavated to a depth up to $1 \mathrm{~m}$ below the modern surface. Stratigraphically, it consists of both natural and anthropogenic stratigraphic units, whose depositional history can be summarized as follows. At the bottom of the archaeological stratigraphy, SU 127 corresponds to a partially cut Pleistocene dune (Ferrer, 2008). A first occupation phase, dated to the Late Mesolithic, consists of several archaeological deposits formed in a grey-brown dark sandy matrix with ashes and organic material, and 16 features: 14 hearths and 2 pit graves with individual inhumations. The site was reoccupied during the Chalcolithic period with a settlement that consisted of pit structures. During and after the Chalcolithic occupation, some ceramic sherds - mostly small fragments $<3 \mathrm{~cm}$ - became incorporated in the underlying Late Mesolithic deposits. Ploughing activities, resulting from later agricultural uses of the area (for crops and grapes), truncated most of the Chalcolithic features and partially altered the Late Mesolithic deposits by mixing materials from both archaeological phases.

The Late Mesolithic phase has rich land-snail assemblages, some faunal remains and diagnostic artefacts such as trapezes

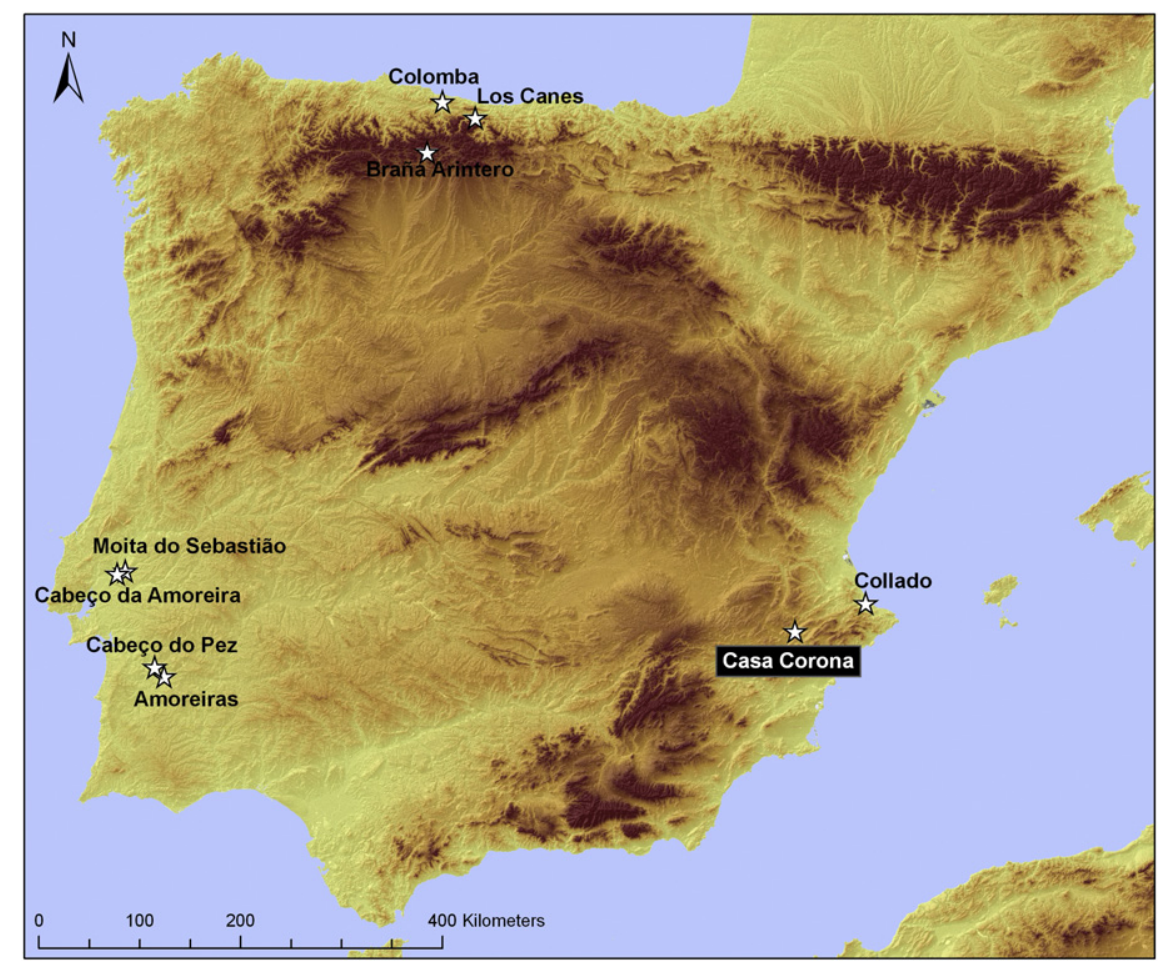

Fig. 1. Late Mesolithic burials with stable isotope paleodietary studies in the Iberian Peninsula. 


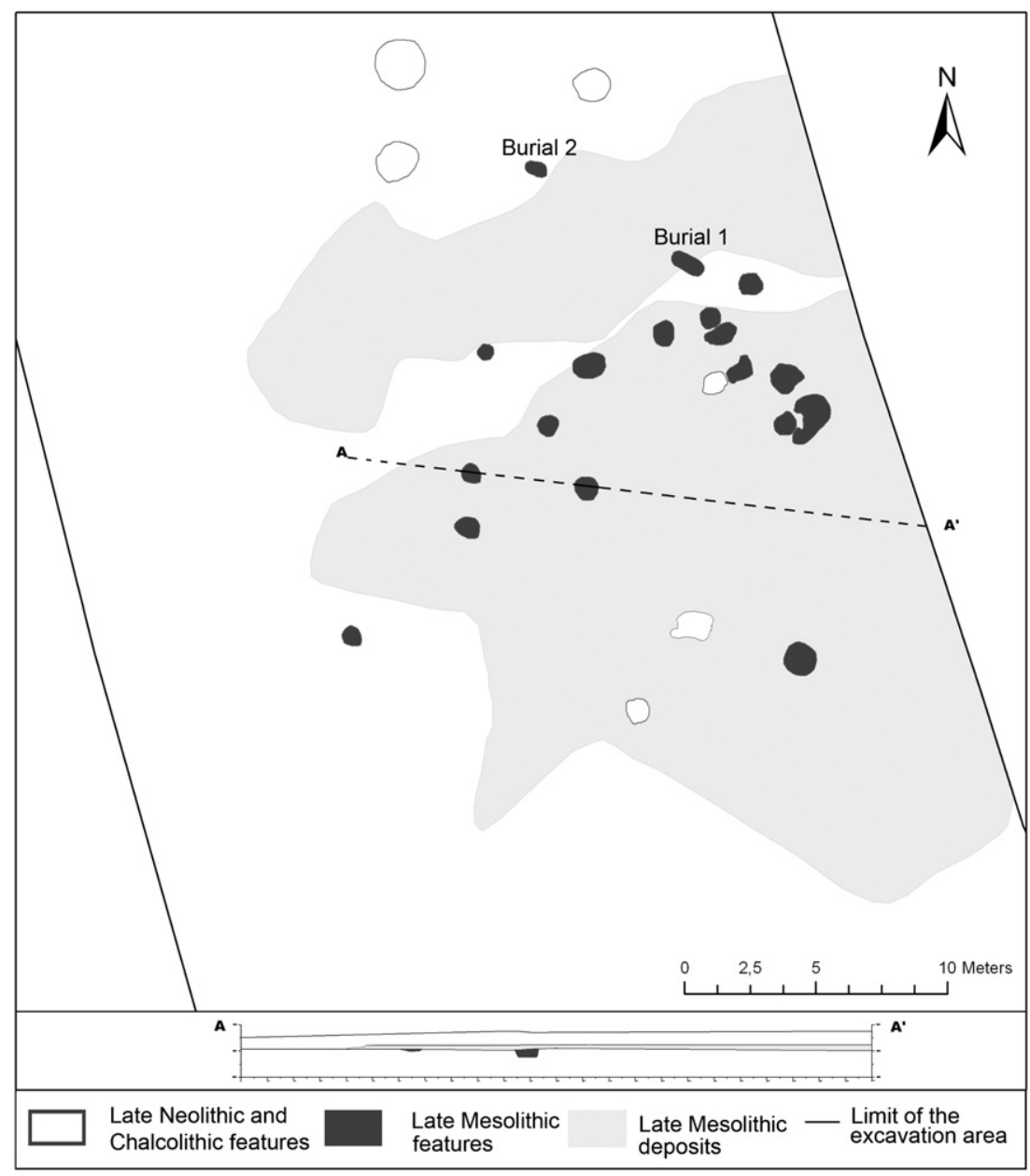

Fig. 2. Casa Corona site. Spatial distribution of Late Mesolithic features and deposits.

and pierced marine shell beads of Columbella rustica. Occupational features such as hearths consist of shallow pit structures excavated into the basal sands of the Pleistocene dune, filled by sediments of burnt sands, fire-cracked stones and continental gastropods. The variability in diameter ranges $(0.6-1.2 \mathrm{~m})$ is a result of the partial overlapping of different hearths over the course of the Mesolithic occupation of the site. Zooarchaeological data are limited owing to the high fragmentation and poor preservation conditions of bones in the sedimentary context of the site. Preliminary reports have outlined the dominance of rabbits among mammals (Oryctolagus cuniculus) and the occasional presence of Testudines (Emydidae/ Bataguridae) at one of the hearths (Morales, 2008). In contrast, land snails are consistently documented in the infill sediments of the 14 hearths and the stratigraphic units with Late Mesolithic materials overlying them. Malacological assemblages are clearly dominated by a medium-sized edible species, Sphincterochila candidissima, and Iberus alonensis. Biometric analysis points to a gathering strategy centred on adult individuals from the immediate vicinity of the site that took place during the spring and/or autumn (Fernández-López de Pablo et al., 2011).

\subsection{The Late Mesolithic burials at Casa Corona}

Two individual pit graves, $7 \mathrm{~m}$ from each other, were documented in the Late Mesolithic occupational area. The spatial distribution of the burials in relation to the hearths suggests an intra-site patterning such that the graves were closely spaced but spatially segregated from the hearths. This implies some kind of symbolic use of the funerary area, since the clustered distribution of hearths, including partial superimpositions, denotes a recurrent use of the same space.

\subsubsection{Burial 1}

Burial 1 is a primary individual interment of an adult woman aged 35-40. The skeleton has a poor state of preservation due to the acidity of the soil. However, the epiphyses of the long bones as well as the vertebral bodies are preserved. The old post mortem fractures prevent the reconstruction of the skeletal pieces. The surfaces of the bones have a crust that prevents observation and reconstruction, especially of the crania. The skeleton is oriented in a NE-SW direction and was placed in a supine position with the face towards the left. The skeleton is in an anatomically natural arrangement; the upper extremities are flexed in the abdominal region, and shoulders are hunched. This arrangement cannot be due to the small dimensions of the grave, as can be seen in the photograph (Fig. 3). On the contrary, the right upper extremity is above the right ribs, not at their side. The thorax is open, indicating that there was enough space around it for it to happen during the stages of decomposition. However, the position of the clavicles indicates a lack of space during decomposition. At the same time, the pelvis is totally closed, and the lower extremities flexed, still leaning against the wall of the grave itself. 


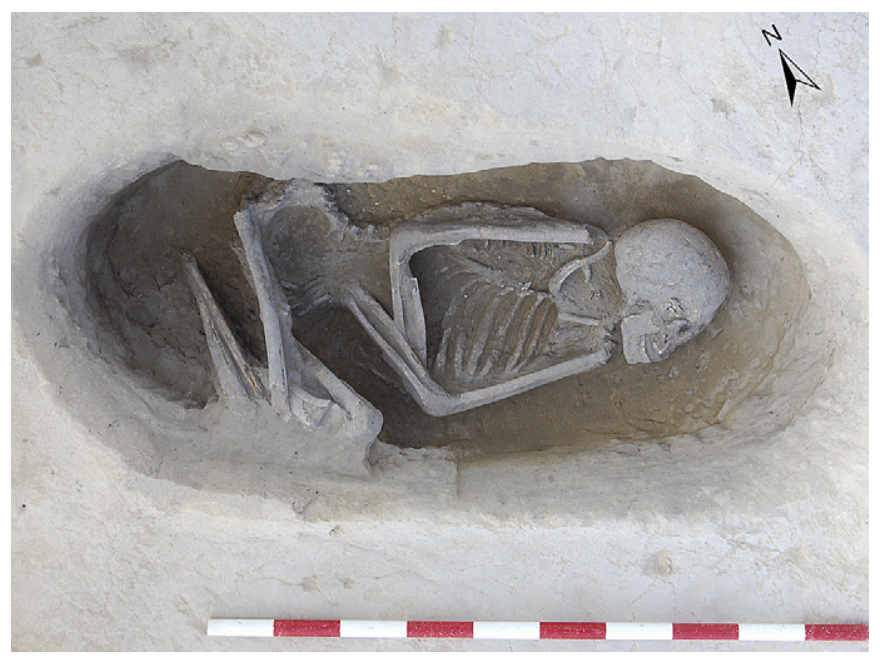

Fig. 3. Casa Corona, burial 1.

The persistence of narrow joints, the forced position of the shoulders and the location of the right arm with respect to the ribs seem to indicate that this individual had been wrapped in a shroud. No preparation of the ground of the burial site was carried out to raise the skull slightly. In spite of this robustness it can be said that in general the postcranial bones are gracile (Drak and Garralda, 2009). The dental study confirms the presence of 3 teeth with evidence of caries, a lower canine with enamel hypoplasia, and fragmented dental calculus.

A pierced shell bead of $C$. rustica and a trapeze were found during the wet sieving of the burial pit fill. However, their intentional association with the burial as grave goods cannot be clearly distinguished from that of other archaeological materials such as lithic debris $(n=211)$, small bone fragments, pieces of charcoal and burnt land snails ( $n=182$ ) randomly found across the burial pit fill.

\subsubsection{Burial 2}

Burial 2 is a primary individual interment of a child aged 1-1.5 according to tooth development (Crétot, 1978; Ubelaker, 1989). The skeleton also has a poor state of preservation. The individual was placed in a supine position and oriented NW-SE. The acidity of the ground destroyed a large part of the postcranial skeleton, and the abdominal region, pelvis and femora are not preserved. The left side of the body, lacking a large part of the arm and the thorax, has also been damaged. In spite of the lack of most of the skeleton, a study of the on-site photographs allows some aspects of the body deposition to be observed (Fig. 4). The skull is raised, with the jaw closely articulated and vertebral arches inside, denoting a position forced by the presence of a perishable object (not preserved) as a pillow under the skull. Such an arrangement allowed the face of the individual to look towards the left shoulder, which leaned in a higher position than the right one. The orientation of the humerus denotes a forced position of the shoulders. The ribs on the right side belong to a closed thorax. Everything seems to reveal that the dead individual was placed in the pit wrapped.

Given the age of the individual of burial 2 and the bad preservation of DNA material (Eva Fernández-Domínguez, personal communication), the sex could not be determined. A flint blade, deposited by the side of the right femur, is the only grave good clearly documented. In addition to this item, some burnt land snails $(n=8)$ and lithic debris $(n=24)$ were randomly found across the burial pit fill, as well as small fragments of charcoal and burnt bones.

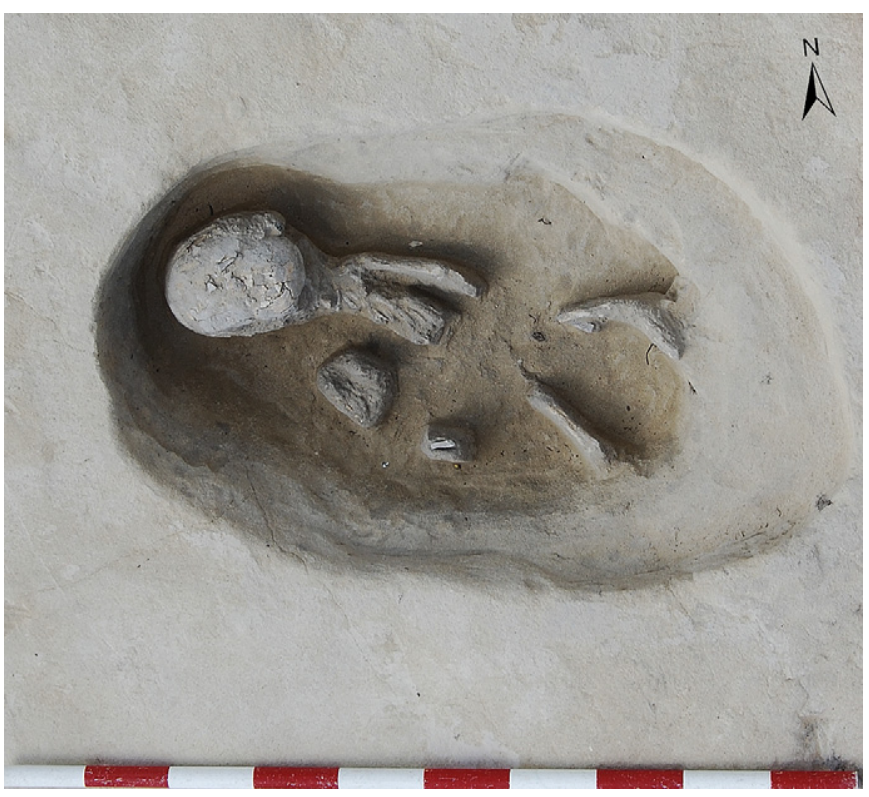

Fig. 4. Casa Corona, burial 2.

\section{Materials and methods}

\subsection{Radiocarbon dating}

Two single human bone samples were selected from each burial for AMS radiocarbon dating: a fragment of right femur from the individual of Burial 1 and a skull fragment from the individual of Burial 2. Bone collagen extraction of individual 1 was undertaken at Beta Analytic Laboratories following their standard procedures (http://www.radiocarbon.com/pretreatment-carbon-dating.htm), while individual 2 was pre-treated at the Department of Human Evolution of the Max Planck Institute for Evolutionary Anthropology (Leipzig, Germany). AMS radiocarbon analyses were performed at Beta Analytic (Beta-272856) and Oxford (OxA-V-239292) laboratories. Calibration of radiocarbon dates was performed using Oxcal v 4.1.3 (Bronk Ramsey, 2009) and IntCal09 (Reimer et al., 2009).

\subsection{Stable isotopic analysis}

A rib fragment from individual 1 and a skull fragment from individual 2 were sampled for carbon and nitrogen stable isotopic analysis. Given the poor state of preservation of the faunal remains from the Late Mesolithic deposits, it was not possible to establish carbon $\left(\delta^{13} \mathrm{C}\right)$ or nitrogen $\left(\delta^{15} \mathrm{~N}\right)$ animal background values with which to compare the human results.

Prior to analysis, visible contaminants were removed by abrasion with aluminium oxide powder. Collagen extraction proceeded following Richards and Hedges (1999), with the addition of an ultrafiltration step (Brown et al., 1988). To summarize, whole bone pieces weighing ca. $300 \mathrm{mg}$ from each of the fragments were demineralized in $0.5 \mathrm{M} \mathrm{HCl}$ solution at $5{ }^{\circ} \mathrm{C}$ for one week, and then rinsed three times with deionized water until the $\mathrm{pH}$ became neutral. This was followed by gelatinization over $48 \mathrm{~h}$ at $70{ }^{\circ} \mathrm{C}$, and later by filtering with a $5 \mu \mathrm{m}$ EZEE $^{\odot}$ filter and ultrafiltering with $>30$ kDa Amicon ${ }^{\odot}$ ultrafilters. The purified solution was finally frozen and lyophilized before being weighed into tin capsules and loaded into the mass spectrometers. The carbon and nitrogen isotope ratios of the collagen were measured in duplicate using a Delta XP continuous-flow isotope-ratio mass spectrometer after 
being combusted in an elemental analyser Flash EA 2112 interfaced with it (Thermo-Finnighan ${ }^{\odot}$, Bremen, Germany), all at the Department of Human Evolution of the Max Planck Institute for Evolutionary Anthropology (Leipzig, Germany). The stable carbon isotope ratios were expressed relative to the VPDB scale (Vienna PeeDee Belemnite), and the stable nitrogen isotope ratios were measured relative to the AIR scale (atmospheric $\mathrm{N}_{2}$ ), using the delta notation $(\delta)$ in parts per thousand $(\%)$. Repeated analysis of internal and international standards determined an analytical error always less than $0.2 \%(1 \sigma)$ for both $\delta^{13} \mathrm{C}$ and $\delta^{15} \mathrm{~N}$.

\section{Results}

\subsection{AMS radiocarbon dating}

The results of the AMS radiocarbon dating are given in Table 1. Both dates $\left(C^{14}\right.$ ages of $7070 \pm 40$ and $7116 \pm 32$ ) are statistically identical $\left(\chi^{2}=0.8, \mathrm{df}=1, p<0.05\right)$ and fall within the 6059-5849 cal BC range, indicating short-term funerary activity in this site. In the Mediterranean region of Spain these dates are from the transition from the Geometric Mesolithic phase A, which is characterized regionally by the dominance of trapezes among the geometric microliths, to phase $\mathrm{B}$, characterized by the dominance of triangles (Martí et al., 2009). Such attribution agrees with the lithic typology from the Late Mesolithic deposits and features at the site, dominated by trapezes. The occasional presence of a Cocina-type triangle confirms this transitional chronology and suggests the abandonment of the site soon after the beginning of phase B (Fig. 5).

\subsection{Stable isotopic analysis}

The collagen from all the samples discussed here is well preserved, meets the published collagen quality indicators $(\% \mathrm{C}, \% \mathrm{~N}$, C:N ratio), and has a collagen yield higher than 1\% (Ambrose, 1990; De Niro, 1985; Van Klinken, 1999). The average results for each duplicate measurement and the collagen quality indicators are shown in Table 2 . The human samples show $\delta^{13} \mathrm{C}$ values compatible with typical terrestrial $C_{3}$ resources $(-19.3 \%$ and $-18.5 \%$ ). No clear isotopic evidence of either marine or freshwater protein input in the diet is observed, since this would have shifted the carbon values positively (marine) or negatively (freshwater). The nitrogen values confirm the lack of an aquatic signature on the bone collagen, since they would be expected to be higher if there was one. Although it could be argued that the $3 \% \delta^{15} \mathrm{~N}$ value difference between the two humans $(8.4 \%$ and $11.6 \%$ o $)$ could reflect a slight aquatic input in the individual with a more positive nitrogen value, that it is the 1.5 year-old individual at the higher trophic level suggests that the variability is due not to dietary differences but to breastfeeding instead. Furthermore, since breastfeeding produces an increase in $\delta^{15} \mathrm{~N}$ equivalent to a trophic position in the food chain and a slight increase in $\delta^{13} \mathrm{C}$ (Fuller et al., 2006), both of which are also traceable in archaeological remains (Mays et al., 2002) similar to the ones described for this infant, it can be confirmed that the infant from Casa Corona was being breastfed and that the diet of the population is a typical $C_{3}$ terrestrial diet.

\section{Discussion}

\subsection{The Final Mesolithic in a regional context}

The AMS radiocarbon results for the Casa Corona burials provide the most recent evidence of Late Mesolithic populations in the Central Mediterranean region of Spain. In this area, existing ${ }^{14} \mathrm{C}$ dates from short-lived individual samples document a chronological gap of five centuries between the last Late Mesolithic and the first Neolithic contexts (Table 3). Fig. 7 illustrates the geographical distribution of the sites plotted in Fig. 6 .

Late Mesolithic occupations dated c. 6500-6100 cal BC are found in the coastal shell midden site of El Collado (Aparicio, 2008) and in archaeological sequences located in the central valleys of the Alicante region, such as Tossal de la Roca (Cacho et al., 1995), Falguera (García-Puchol and Aura, 2006) and Santa Maira (Aura et al., 2006) (Fig. 7A).

During the next phase (c. 6100-5800 cal BC), neither radiocarbon dates nor Mesolithic lithic assemblages are documented in any of this area except the upper Vinalopó Valley (Fig. 7B), at the innermost extreme of this network of Mesolithic settlements. Even though the lack of Mesolithic occupations might be partially explained by taphonomic biases - sites such as Tossal de la Roca and Falguera evidence an erosive hiatus between the Late Mesolithic and the first Neolithic layers - regional survey programs have not provided surface collections or sites dated to the Final Mesolithic either (Bernabeu et al., 2008). Hence, this pattern suggests that both the coast and the inner mountain valleys of the north Alicante region were only marginally occupied during this phase.

In contrast, evidence from the Final Mesolithic (c. 61005800 cal BC) is found at various archaeological sites in the upper Vinalopó Valley. The lithic scatter of Casa de Lara, situated $2 \mathrm{~km}$ south of Casa Corona, yielded a surface collection with Late Mesolithic trapezes and triangles attributed to phases A and B (Fernández-López de Pablo, 1999). Nevertheless, this lithic assemblage clearly shows a significantly lower quantity of phase B microliths (13 Cocina-type triangles) in relation to the previous Geometric Mesolithic phase A (124 trapezes with concave sides), suggesting a shorter chronological length for phase B at the site. The second Final Mesolithic site is Lagrimal cave, a disturbed archaeological deposit that contains some Late Mesolithic materials such as trapezes, microburins and C. rustica shell beads (Soler García, 1991). Radiocarbon dating of an ulna bone of an ibex with anthropogenic fractures and cut marks from level IV of this cave has yielded the most advanced Late Mesolithic date in this area (Fernández-López de Pablo and Gómez-Puche, 2009).

On the basis of radiocarbon determinations of domesticated specimens, the earliest Neolithic contexts (Fig. 7C), associated with Tyrrhenian and Ligurian Impressed ceramic facies and predating the development of the Cardial Culture, are dated to around 56505400 cal BC both at hamlets (Mas d'Is and Barranquet) and cave sites (Cova d'en Pardo) (Bernabeu et al., 2010; García-Atiénzar, 2010; McClure et al., 2008).

Consequently, the radiocarbon dates of Casa Corona and Lagrimal cave represent the most recent evidence of Late Mesolithic settlement in this area. The two-sigma chronology ranges are

Table 1

AMS radiocarbon dates of the Late Mesolithic burials of Casa Corona.

\begin{tabular}{|c|c|c|c|c|c|c|}
\hline Context & Age (yr) & Lab Ref. & $\mathrm{C}: \mathrm{N}$ & ${ }^{14} \mathrm{C}$ Age BP & cal BC $1 \sigma$ & cal BC $2 \sigma$ \\
\hline Burial 1 & $35-40$ & Beta-272856 & nd & $7070 \pm 40$ & $6002-5971(27.1 \%)$ & $6023-5877$ (94.6\%) \\
\hline & & & & & $5954-5910(41.1 \%)$ & $5856-5849(0.8 \%)$ \\
\hline Burial 2 & 1.5 & OxA-V-2392-92 & 3.4 & $7116 \pm 32$ & $\begin{array}{l}6024-5982(60.1 \%) \\
5940-5930(8.1 \%)\end{array}$ & $\begin{array}{l}6058-5974(77.18 \%) \\
5950-5918(17.6 \%)\end{array}$ \\
\hline
\end{tabular}



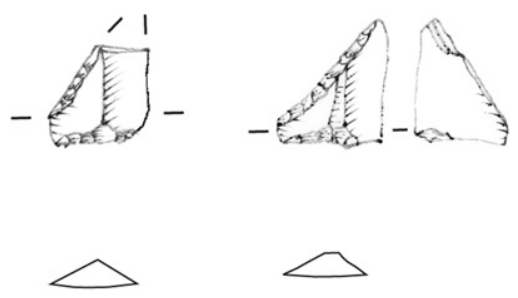

1
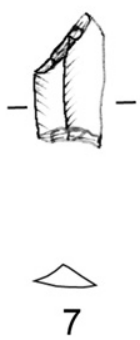

7
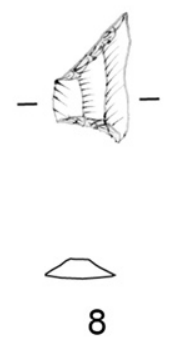

2
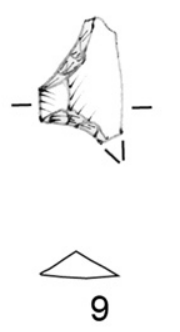
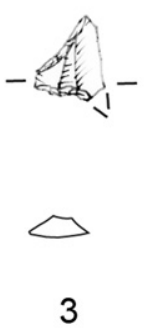

3
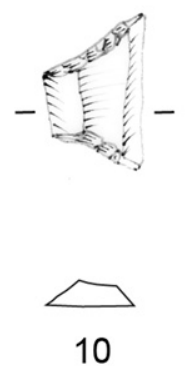
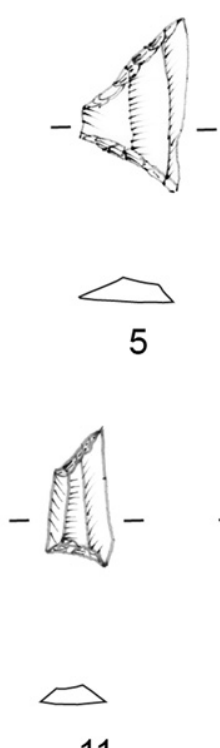

11
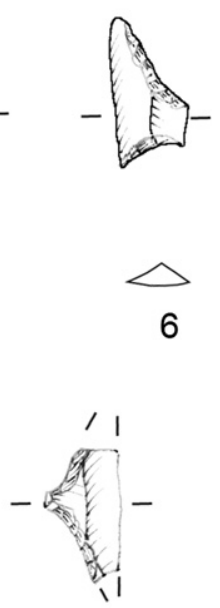

12

Fig. 5. Late Mesolithic microliths of Casa Corona features and archaeological deposits.

statistically different from both the previous Late Mesolithic and the subsequent Early Neolithic contexts.

\subsection{Late Mesolithic palaeodietary patterns in the Iberian Peninsula}

The samples from Casa Corona show no marine isotopic signal in the diet, suggesting that in terms of subsistence this population did not have any direct and regular dietary contact with the sea. With respect to other Iberian Late Mesolithic data sets, these results must be interpreted in the light of different geographical and chronological patterns pertaining to reliance on marine foods. On the Muge river (central Portugal), the first stable isotopic studies undertaken on samples from Cabeço da Arruda and Moita do Sebastiao revealed that Late Mesolithic dietary patterns relied on aquatic resources to the extent of about $35-45 \%$, in sharp contrast with Neolithic diets based primarily on terrestrial foods (Lubell et al., 1994). New studies, however, indicate a diachronic variability in the reliance on aquatic foods, depending on changes in the estuarine regime and shellfish availability (Bicho et al., 2010). Thus, an abrupt increase in shellfish consumption is related to the establishment of rich shell beads induced by the regional effects of the $8.2 \mathrm{kyr}$ cal BP event on coastal upwelling activity (Bicho et al., 2010). Soon after, a gradual decrease in the intertidal influence (van der Shrieck et al., 2007), and consequently in shellfish availability, was mirrored by a progressively reduced signal of proteins of aquatic origin in Mesolithic palaeodiets (Jackes and Meiklejohn, 2004; Roksandic, 2006). At the Sado estuary, the shell midden of Arapouco reflects a comparable input of aquatic protein to that of the Muge sites (35-45\% marine protein), while other Late Mesolithic sites located far inland, such as Amoreiras and Cabeço do Pez,

Table 2

$\delta^{13} \mathrm{C}$ and $\delta^{15} \mathrm{~N}$ isotopic values of Casa Corona human samples.

\begin{tabular}{llllclll}
\hline S-Eva & Context & Age & $\delta^{13} \mathrm{C}(\%)$ & $\delta^{15} \mathrm{~N}(\% \mathrm{o})$ & $\% \mathrm{C}$ & $\% \mathrm{~N}$ & $\mathrm{C}: \mathrm{N}$ \\
\hline 16,462 & Burial 1 & $35-40$ & 19.3 & 8.4 & 35.4 & 12.3 & 3.4 \\
16,463 & Burial 2 & 1.5 & 18.5 & 11.6 & 39.3 & 13.6 & 3.4 \\
\hline
\end{tabular}

yield a more terrestrial diet (Umbelino, 2006). This dual pattern suggests the geographical coexistence of neighbouring human groups with varying reliance on aquatic and terrestrial resources.

At the coastal Eastern Iberian Late Mesolithic site of El Collado, just $70 \mathrm{~km}$ from Casa Corona, a sample composed of 9 adult skeletons provides isotopic evidence of a variable $C_{3}$ terrestrial diet with as much as $25 \%$ marine protein input for just two of the individuals (Fig. 8) (García-Guixé et al., 2006). However, recently published radiocarbon data (Aparicio, 2008) cast doubts on the chronological homogeneity of this necropolis, indicating a more extended funerary use of this site than previously thought. Two new radiocarbon determinations from individuals 4 (8690 \pm 100 BP, 8185-7551 cal BC) and 6 (8080 \pm 60 BP 7301-6779 cal BC) yielded an older age, falling within the so-called Notched and Denticulated Mesolithic from the Boreal period. One of these skeletons, individual 4, exhibits the highest level of aquatic protein intake, around $25 \%$, while the others exhibit lower values or fully terrestrial diets (García-Guixé et al., 2006). Even considering the problems of chronological attribution for part of the El Collado sample, given that only three skeletons have been directly dated and there are older Mesolithic occupations with burials, the differences between this site and Casa Corona suggest a different palaeodietary pattern between coastal and inland sites in the Central Mediterranean region of Spain.

Comparable instances of individuals inhabiting inland patches and exhibiting fully terrestrial diets who coexisted with nearby coastal or estuarine populations with a higher reliance on marine foods have recently been reported in other Iberian regions such as Portugal and Cantabria in the Late Mesolithic. At Cueva de los Canes, five stable isotopic determinations on three different individuals show a subsistence pattern dominated by terrestrial diets (Arias, 2007). Such results are mirrored at the site of Braña Arintero, where two adult individuals yielded no signal of marine protein input in their diets (Arias and Schulting, 2010). In contrast, a single isotopic determination from the nearby coastal site of Colomba, which is just $30 \mathrm{~km}$ from Los Canes and $50 \mathrm{~km}$ from Braña Arintero, yields a clear $50 \%$ marine protein signal (Arias, 2007). 
Table 3

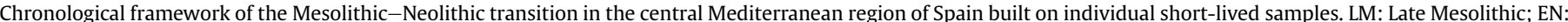

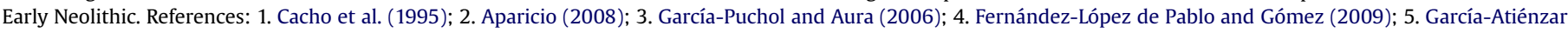
(2010); 6. Bernabeu et al. (2010); 7. Present work.

\begin{tabular}{|c|c|c|c|c|c|c|c|c|c|c|}
\hline Site and context & Affiliation & Sample & Lab ref. & Method & ${ }^{14} \mathrm{C}$ Age BP & cal BC $1 \sigma$ & & cal BC 20 & & Ref. \\
\hline T.de la Roca, I & LM & Bone indet & Gif-6898 & Conv & $7660 \pm 60$ & -6567 & -6452 & -6630 & -6425 & 1 \\
\hline Collado, burial 13 & LM & Human bone & UBAR-281 & Conv & $7640 \pm 120$ & -6631 & -6398 & -6770 & -6232 & 2 \\
\hline Collado, burial 13 & LM & Human bone & UBAR-280 & Conv & $7570 \pm 180$ & -6602 & -6234 & -7002 & -6054 & 2 \\
\hline T.de la Roca, I & LM & Bone indet & Gif-6897 & Conv & $7560 \pm 60$ & -6469 & -6377 & -6557 & -6249 & 1 \\
\hline Falguera, VIII & LM & Bactrea Pinus & AA-59519 & AMS & $7526 \pm 44$ & -6446 & -6370 & -6461 & -6255 & 3 \\
\hline Falguera, II & LM & Olea & AA-2295 & AMS & $7410 \pm 70$ & -6377 & -6225 & -6425 & -6096 & 3 \\
\hline Corona, burial 2 & LM & Human bone & OxA-V-2392-27 & AMS & $7116 \pm 32$ & -6023 & -5928 & -6056 & -5916 & 7 \\
\hline Corona, burial 1 & LM & Human bone & Beta-272856 & AMS & $7070 \pm 40$ & -6000 & -5909 & -6021 & -5847 & 7 \\
\hline Lagrimal, IV & LM & Capra pyrenaica & Beta-249933 & AMS & $6990 \pm 50$ & -5975 & -5809 & -5983 & -5753 & 4 \\
\hline En Pardo, VIII inf & EN & Capra pyrenaica & Beta-231880 & AMS & $6660 \pm 40$ & -5627 & -5558 & -5657 & -5511 & 5 \\
\hline En Pardo, VIII & EN & Ovis/capra & Beta-231879 & AMS & $6610 \pm 40$ & -5614 & -5514 & -5619 & -5487 & 5 \\
\hline Mas d'Is, house 2 & EN & Hordeum $v$. & Beta-166727 & AMS & $6600 \pm 50$ & -5609 & -5488 & -5619 & -5479 & 6 \\
\hline Mas d'Is, house 1 & EN & Hordeum v. & Beta-162092 & AMS & $6600 \pm 50$ & -5609 & -5488 & -5619 & -5479 & 6 \\
\hline Falguera, VI & EN & Triticum m. & Beta-142289 & AMS & $6510 \pm 80$ & -5538 & -5374 & -5614 & -5322 & 3 \\
\hline Barranquet, UE79 & EN & Ovis aries & Beta-221431 & AMS & $6510 \pm 50$ & -5538 & -5381 & -5605 & -5365 & 6 \\
\hline Cendres, H19 & EN & Ovis aries & Beta-239377 & AMS & $6510 \pm 50$ & -5538 & -5381 & -5605 & -5365 & 6 \\
\hline
\end{tabular}

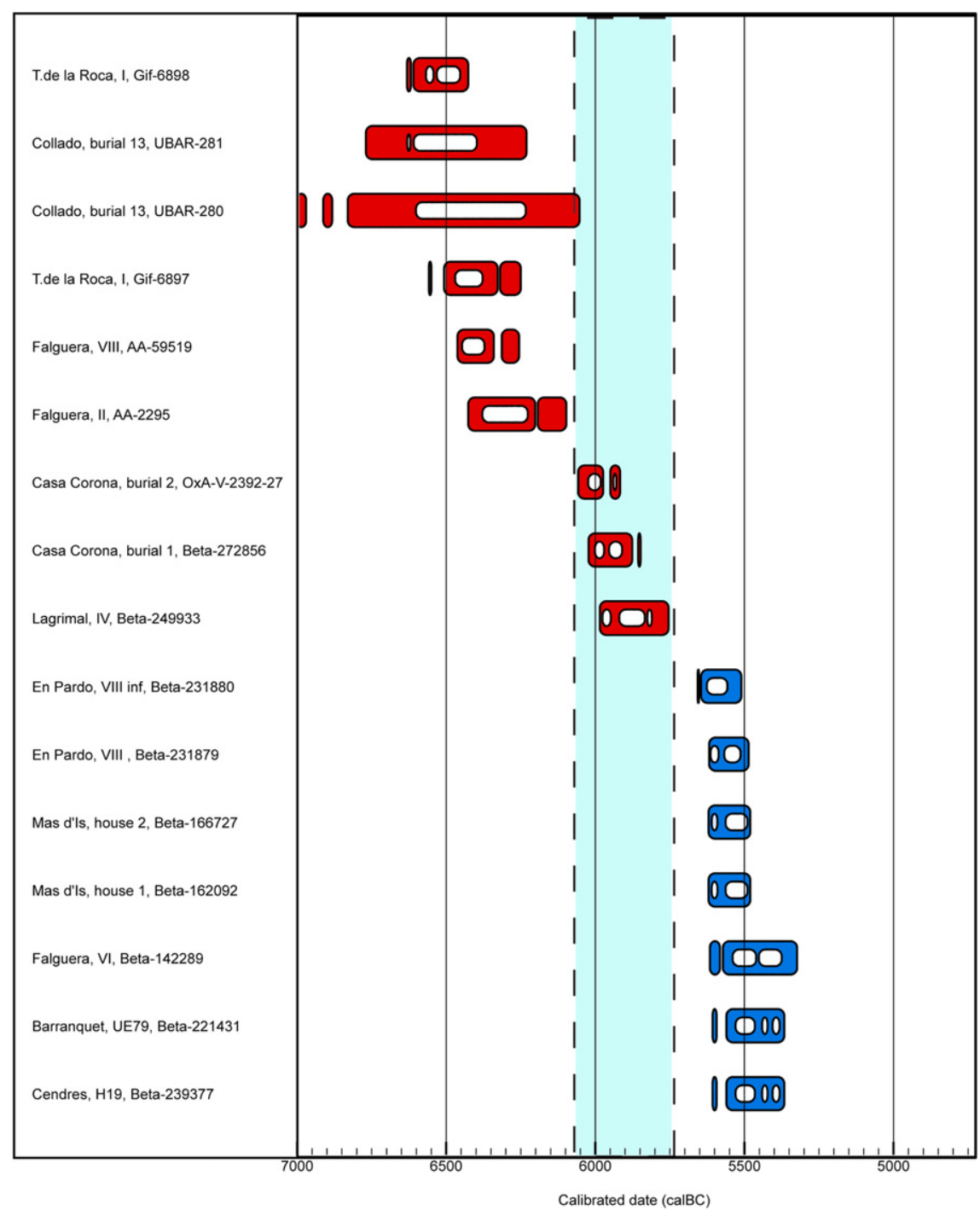

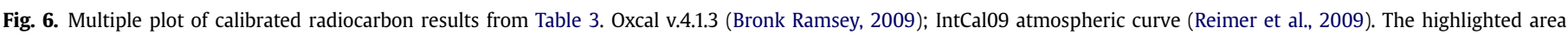
represents the previously known chronological gap, now filled by the dates of Casa Corona and Lagrimal sites. 


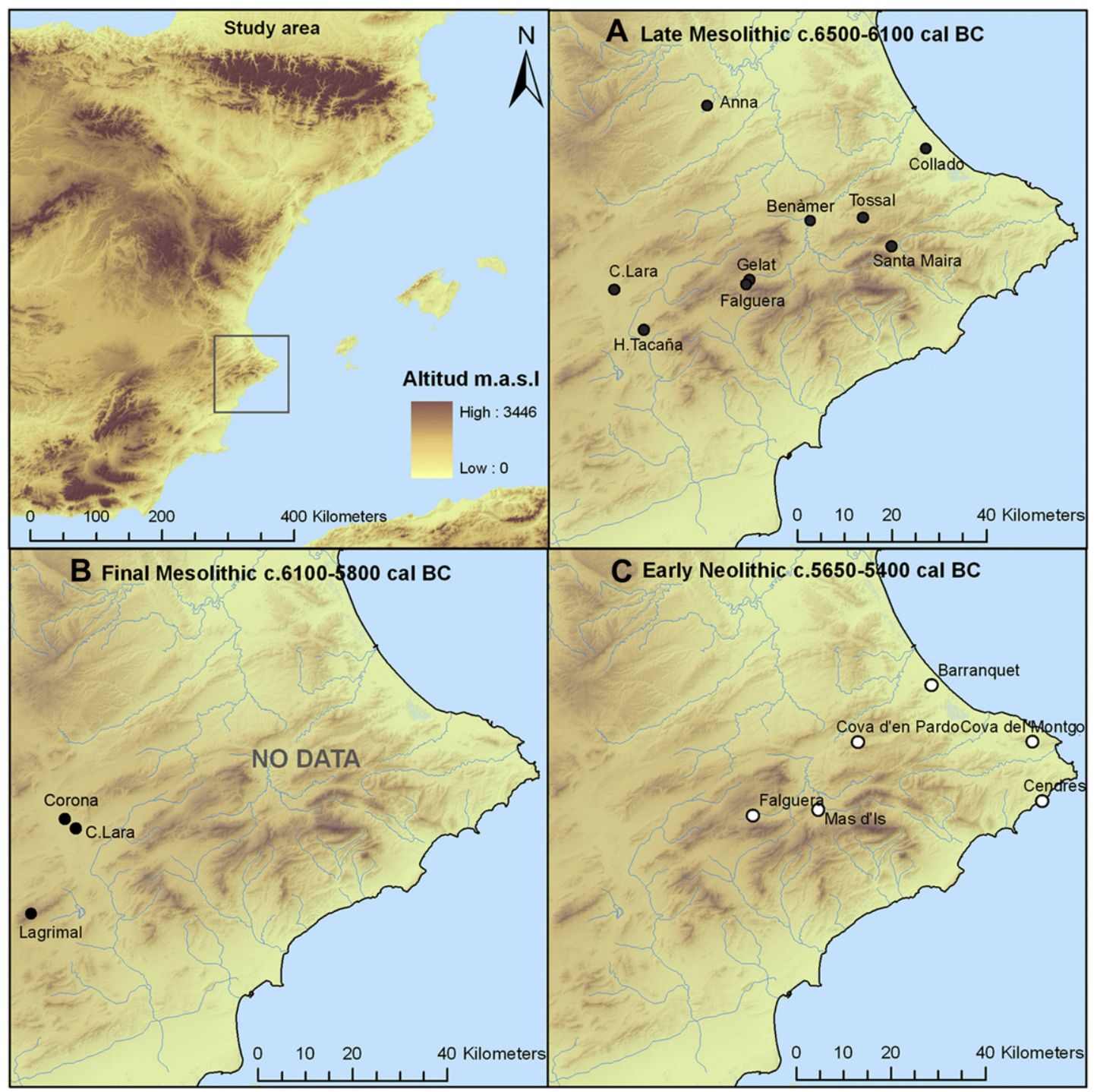

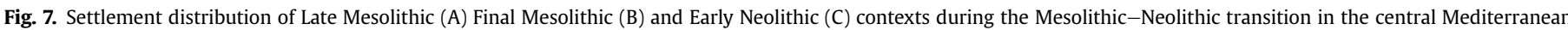
region of Spain.

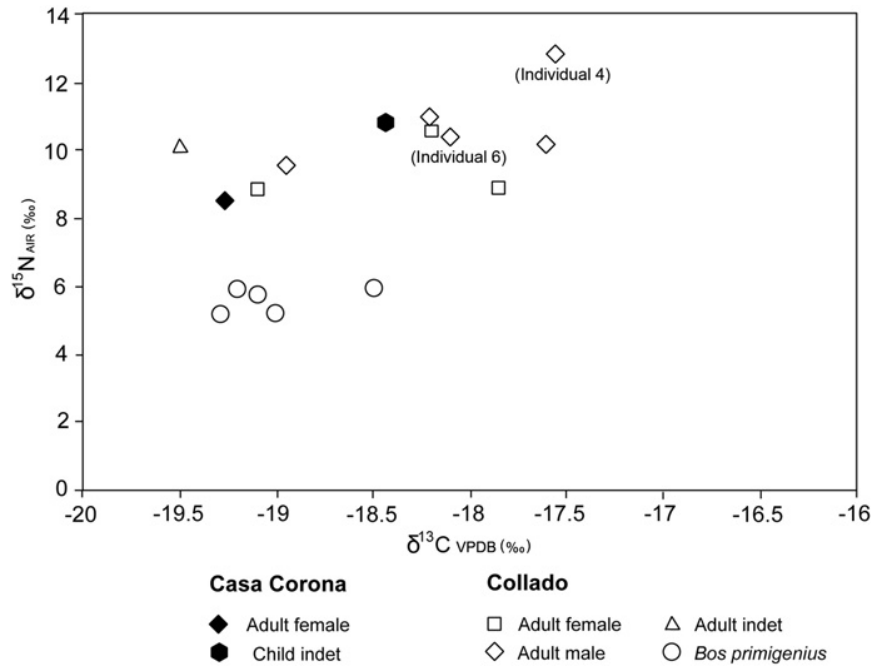

Fig. 8. Plot of $\delta^{13} \mathrm{C}$ and $\delta^{15} \mathrm{~N}$ stable isotopic values from Mesolithic human samples of Casa Corona and El Collado in the central Mediterranean region of Spain.

\section{Conclusions}

The results shed new light on the chronology and subsistence patterns of the last Mesolithic communities in the central Mediterranean region of the Iberian Peninsula. The age of the burials at Casa Corona is statistically different from the earliest Neolithic sites found at coastal locations or in the inland valleys of this region. In other words, regarding the Neolithic transition, as far as radiometric data from short-lived samples of human remains and domesticated specimens are concerned, no chronological coexistence between farmers and foragers is documented in the archaeological record of this area. This pattern might be the result of a very short interaction phase taking place during and soon after the first Neolithic settlements appeared in this area, which has not left a visible trace in Final Mesolithic contexts. This process would then have ended with a rapid assimilation of local hunter-gatherer communities lasting only three to four generations.

The main question that is raised is why the last Mesolithic foragers were assimilated so quickly in the Central Mediterranean 
region of Spain. As suggested by the evidence from palaeodietary data, Late Mesolithic subsistence was heavily dependent on terrestrial resources. This reinforces the idea of Late Mesolithic populations as small groups exploiting diversified and patchy environments. Furthermore, given the low reliance on marine resources, it could be expected that higher residential mobility patterns would have negatively affected the demography of local forager communities by imposing structural limits to their growth capacity.

\section{Acknowledgements}

Post-excavation multidisciplinary research at Casa Corona site is being undertaken as a research project by J.F.L. named Mediterranean Archaeological Landscapes: Postpaleolithic adaptations, paleodemography and land use patterns, from the Ramón y Cajal research program (MICINN, Ref. RYC-09363).

Stable isotopic analysis was carried out by D.C.S.G as a part of his PhD. Project named Isótopos, dieta y movilidad en el País Valenciano. Aplicación a restos humanos del Paleolítico medio al Neolítico final supported by FPU research program (Ref. AP2005-1509) of the Ministerio de Ciencia e Innovación (MICINN). The study of anthropological remains is part of the research project named Estudio de las características antropológicas de las poblaciones en transición mesolítico-neolítico del nordeste de la Península Ibérica (MICINN, Ref. CGL2009-07572-E/BOS) hold up by E.S.G.

All authors would like to acknowledge to Mr. José Ramón Ortega and Mr.Juan de Dios Boronat (Arpa Patrimonio S.L.) for let us access to unpublished materials from Casa Corona site and the MaxPlanck Society (Prof. Jean-Jacques Hublin) for funding the carbon and nitrogen isotope analyses. We thank two anonymous reviewers for their careful comments on a previous version of this manuscript.

\section{References}

Ambrose, S.H., 1990. Preparation and characterization of bone and tooth collagen for isotopic analysis. Journal of Archaeological Science 17, 431-451.

Ammermann, A.J., Cavalli-Sforza, L.L., 1984. The Neolithic Transition and the Genetics of Populations in Europe. Princeton University Press, Princeton.

Aparicio, J., 2008. La necrópolis mesolítica de El Collado (Oliva-Valencia). Varia VIII. Diputación provincial de Valencia.

Arias, P., 2007. Neighbours but diverse: social change in northwest Iberia during the transition from the Mesolithic to the Neolithic (5500-4000 cal BC). In: Whittle, A., Cummings, V. (Eds.), Going Over: the Mesolithic-Neolithic Transition in North-West Europe. Oxford University Press, Oxford, pp. 53-71.

Arias, P., Schulting, R., 2010. Análisis de isótopos estables sobre los restos humanos de La Braña-Arintero. Aproximación a la dieta de los grupos mesolíticos de la cordillera Cantábrica. In: Vidal, J.M., Prada, M.E. (Eds.), Los hombres mesolíticos de la cueva de la Braña-Arintero (Valdelugueros, León). Junta de Castilla y León, Consejería de Cultura y Turismo, pp. 130-137.

Aura, J.E., Carrión, Y., García, O., Jardón, P., Jordá, J.F., Molina, Ll., Morales Pérez, J.V. Pascual, J.Ll., Pérez, G., Pérez, M., Rodrigo, M.J., Verdasco, C., 2006. Epipaleolítico-Mesolítico en las comarcas centro-meridionales valencianas. In: Alday, A. (Ed.), El mesolítico de muescas y denticulados en la cuenca del Ebro y el litoral mediterráneo peninsular. Diputación Foral de Álava. Departamento de Cultura, Álava, pp. 65-120.

Bernabeu, J., Molina, L., García-Borja, P., 2010. Le Néolithique ancien valencien Caractérisation des productions ceramiques. In: Manen, C., Convertini, F. Binder, D., Sénépart, I. (Eds.), Premières sociétés paysannes de Méditerranée occidentale. Structures des productions céramiques. Societé Préhistorique Fançanise, Mémoire 51, pp. 215-225.

Bernabeu, J., Molina, Ll., Orozco, T., Díez, A., Barton, C.M., 2008. Los Valles del Serpis (Alicante): 20 años de trabajos de campo. Actas del IV Congreso del Neolítico Peninsular. In: Museo Arqueológico de Alicante. Diputación Provincial de Alicante, Alicante, pp. 50-57.

Biagi, P., 2003. A review of the Late Mesolithic in Italy an its implication for the Neolithic transition. In: Ammerman, A.J., Biagi, P. (Eds.), The Widening Harvest Archaeological Institute of America, Boston, pp. 132-156.

Bicho, N., Umbelino, C., Detry, C., Pereira, T., 2010. The emergence of the Muge Mesolithic shellmiddens (central Portugal) and the 8200 cal yr BP cold event. Journal of Island and Coastal Archaeology 5, 86-104.
Binder, D., 2000. Mesolithic and Neolithic interaction in Southern France and Northern Italy: new data and current hypothesis. In: Price, T.D. (Ed.), Europe's First Farmers. Cambridge University Press, Cambridge, pp. 117-143.

Bronk Ramsey, C., 2009. Bayesian analysis of radiocarbon dates. Radiocarbon 51 (1), 337-360.

Brown, T.A., Nelson, D.E., Vogel, J.S., Southon, J.R., 1988. Improved collagen extraction by modified Longin method. Radiocarbon 30, 171-177.

Cacho, C., Fumanal, M.P., López, P., López, J.A., Pérez, M., Martínez, R., Uzquiano, P., Arnanz, A., Sánchez, A., Sevilla, P., Morales, A., Roselló, E., Garralda, M.D. García, M., 1995. El Tossal de la Roca (Vall d’Alcalá, Alicante). Recerques del Museu d'Alcoi 4, 11-101.

Crétot, M., 1978. L'arcade dentaire humaine. Morphologie. Julien Prélat, Paris.

De Niro, M.J., 1985. Postmortem preservation and alteration of in vivo bone collagen isotope ratios in relation to palaeodietary reconstruction. Nature 317, 806-809.

Drak, L., Garralda, M.D., 2009. Restos humanos mesolíticos en la cordillera cantábrica (Norte de España). Estudios de Antropología Biológica XIV-I, 261-282.

Fernández-López de Pablo, J., 1999. El yacimiento prehistórico de Casa de Lara. In: Cultura material y producción lítica. Fundación José María Soler, 163 pp.

Fernández-López de Pablo, J., Gómez-Puche, M.M., 2009. Climate change and population dynamics during the Late Mesolithic and the Neolithic transition in Iberia. Documenta Praehistorica 36, 67-96.

Fernández-López de Pablo, J., Gómez-Puche, M.M., Martínez-Ortí, A., 2011. Systematic consumption of non-marine gastropods at open-air Mesolithic sites in the Iberian Mediterranean Region. Quaternary International 244, 45-53.

Ferrer, C., 2008. Estudio geomorfológico. In: Estudios sedimentológicos, polínicos, faunísticos, antracológicos, carpológicos y de los restos humanos del yacimiento de La Corona (Villena), dentro de la obra AVE tramo Caudete-Villena P.K. $004+160$ al P.K. $004+360$. Villena (Alicante). Unpublished report.

Fuller, B.T., Fuller, J.L., Harris, D.A., Hedges, R.E.M., 2006. Detection of breastfeeding and weaning in modern human infants with carbon and nitrogen stable isotope ratios. American Journal of Physical Anthropology 129, 279-293.

García-Atiénzar, G., 2010. Las comarcas centromeridionales valencianas en el contexto de la Neolitización de la fachada noroccidental del Mediterráneo. Trabajos de Prehistoria 67 (2), 37-58.

García-Puchol, O., Aura, J.E., 2006. El Abric de la Falguera (Alcoi, Alacant): 8000 años de ocupación humana en la cabecera del rio Alcoi. Diputación Provincial de Alicante, Alicante.

García-Guixé, E., Subirà, M.E., Richards, M.P., 2006. Paleodiets of humans and fauna from the Spanish Mesolithic site of El Collado. Current Anthropology 47 (3), 549-556.

Guilaine, J., Manen, C., 2007. From Mesolithic to Early Neolithic in the western Mediterranean. Proceedings of the British Academy 144, 21-55.

Jackes, M., Meiklejohn, C., 2004. Building a method for the study of the MesolithicNeolithic transition in Portugal. Documenta Praehistorica 31, 89-111.

Lubell, D., Jackes, M., Schwarcz, H., Knyf, M., Meiklejohn, C., 1994. The MesolithicNeolithic transition in Portugal: isotopic and dental evidence of diet. Journal of Archaeological Science 21, 201-216.

Martí, B., Aura, J.E., Juan-Cabanilles, J., García-Puchol, O., Fernández-López de Pablo, J., 2009. El Mesolítico Geométrico de tipo "Cocina" en el País Valenciano. In: Utrilla, P., Montes, L. (Eds.), El Mesolítico Geométrico en la Península Ibérica. Monografía Arqueológica 44. Universidad de Zaragoza, Dpto. Ciencias de la Antigüedad, Área de Prehistoria, Zaragoza, pp. 205-258.

Mays, S.A., Richards, M.P., Fuller, B.T., 2002. Bone stable isotope evidence for infant feeding in Mediaeval England. Antiquity 76, 654-656.

McClure, S.B., Molina, Ll, Bernabeu, J., 2008. Neolithic rock art in context: landscape history and the transition to agriculture in Mediterranean Spain. Journal of Anthropological Archaeology 27, 326-337.

Morales, J.V., 2008. Estudio zooarqueológico. In: Estudios sedimentológicos, polínicos, faunísticos, antracológicos, carpológicos y de los restos humanos del yacimiento de La Corona (Villena), dentro de la obra AVE tramo Caudete-Villena P.K. $004+160$ al P.K. $004+360$. Villena (Alicante). Unpublished results.

Reimer, P.J., Baillie, M.G.L., Bard, E., Bayliss, A., Beck, J.W., Blackwell, P.G., Bronk Ramsey, C., Buck, C.E., Burr, G.S., Edwards, R.L., Friedrich, M., Grootes, P.M., Guilderson, T.P., Hajdas, I., Heaton, T.J., Hogg, A.G., Hughen, K.A., Kaiser, K.F., Kromer, B., McCormac, F.G., Manning, S.W., Reimer, R.W., Richards, D.A., Southon, J.R., Talamo, S., Turney, C.S.M., van der Plicht, J., Weyhenmeyer, C.E., 2009. INTCAL 09 and MARINE09 radiocarbon age calibration curves, $0-50,000$ years Cal BP. Radiocarbon 51 (4), 1111-1150.

Richards, M.P., Hedges, R.E.M., 1999. Stable isotope evidence for similarities in the types of marine foods used by Late Mesolithic humans at sites along the Atlantic coast of Europe. Journal of Archaeological Science 26, 122-131.

Roksandic, M., 2006. Analysis of burials from the new excavations of the sites Cabeço da Amoreira and Cabeço da Arruda (Muge, Portugal). In: Ferreira, Rolão y (Ed.), Do Epipaleolítico ao Calcolítico na Península Ibérica. Actas do IV Congresso de Arqueologia Peninsular, Promontoria Monográfica 4. Universidade do Algarbe, Faro, pp. 43-54.

Rowley-Conwy, P., 2011. Westward Ho! The spread of agriculture from central Europe to the Atlantic. Current Anthropology 52 (Suppl. 4), 431-451.

Soler García, J.M., 1991. La cueva del Lagrimal: Villena (Alicante)-Yecla (Murcia). Fondo Editorial de la Caja de Ahorros Provincial, Alicante.

Ubelaker, D.H., 1989. Human Skeletal Remains. Excavation, Analysis, Interpretation, first ed.. In: Manuals on Archeology 2 Taraxacum, Washington.

Umbelino, C., 2006. Outros sabores do Passado. As análises de oligoelementos e de isótopos estáveis na reconstrução da dieta das comunidades humanas do Mesolítico Final e do Neolítico Final/Calcolítico do território português. 
Unpublished doctoral dissertation. Coimbra: Faculdade de Ciências e Tecnologia, Universidade de Coimbra.

van der Shrieck, T., Passmore, D.G., Rolão, J., Stevenson, A.C., 2007. Estuarine-fluvial floodplain formation in the Holocene Lower Tagus valley (central Portugal) and implications for Quaternary fluvial system evolution. Quaternary Science

Reviews 26, 2937-2957.
Van Klinken, G.J., 1999. Bone collagen quality indicators for palaeodietary and radiocarbon Measurements. Journal of Archaeological Science 26, 687-695.

Zilhão, J., 2003. The Neolithic transition in Portugal and the role of demic diffusion in the spread of agriculture across West Mediterranean Europe. In: Ammerman, A.J., Biagi, P. (Eds.), The Widening Harvest. Archaeological Institute of America, Boston, pp. 207-223. 